\title{
Autori članaka
}

\section{Zoran BAJIN}

Univerzitetska biblioteka „Svetozar

Marković", Beograd

Alberto BeCherelli, dr. sc. Sapienza - Università di Roma

Martina Bitunjac, dr. sc. Sapienza - Università di Roma

Dragomir Bondžıć, dr. sc. Institut za savremenu istoriju, Beograd

Jadranka BRNČIĆ, dr. sc. Filozofski fakultet Sveučilišta u Zagrebu

Ivana Cvijović Javorina

III. gimnazija, Zagreb / doktorandica Poslijediplomskoga doktorskog studija moderne i suvremene hrvatske povijesti u europskom i svjetskom kontekstu

Daniela ČANČAR doktorandica Poslijediplomskog studija „Humanističke znanosti” Sveučilišta u Zadru, studijski smjer Filologija

Sava Damjanov, prof. dr. sc.

Odsek za srpsku književnost Filozofskog fakulteta Univerziteta u Novom Sadu

Bojan ĐorĐEVIĆ, doc. dr. sc.

Institut za književnost i umetnost, Beograd i Filološki fakultet Univerziteta u Beogradu

Vlatka Filipčić Maligec Muzeji Hrvatskog zagorja - Muzej seljačkih buna, Gornja Stubica

Ante Grubišrć

Muzej Slavonije Osijek, Povijesni odjel

Milan Gulić, dr. sc.

Institut za savremenu istoriju, Beograd

Marina Jemrić

Osnovna škola Julija Benešića Ilok / doktorandica Poslijediplomskog studija „Humanističke znanosti” Sveučilišta u Zadru, studijski smjer Filologija
Snježana Koren, dr. sc.

Odsjek za povijest Filozofskog fakulteta Sveučilišta u Zagrebu

Zvonko Kovač, prof. dr. sc.

Odsjek za južnoslavenske jezike i književnosti Filozofskog fakulteta Sveučilišta u Zagrebu

Ivana LATKOvić, dr. sc.

Odsjek za južnoslavenske jezike i književnosti Filozofskog fakulteta Sveučilišta u Zagrebu

Miranda Levanat-Peričić, doc. dr. sc.

Odjel za kroatistiku i slavistiku - Odsjek za hrvatski jezik i književnost Sveučilišta u Zadru

Aleksandar Lukić

Institut za noviju istoriju Srbije, Beograd

Petar Macut

Institut društvenih znanosti Ivo Pilar, Zagreb

Ivan Majić, dr. sc.

Odsjek za južnoslavenske jezike i književnosti Filozofskog fakulteta Sveučilišta u Zagrebu

Miodrag Maticki, dr. sc. Institut za književnost i umetnost, Beograd

Željko Milanović, dr. sc. Odsek za srpsku književnost Filozofskog fakulteta Univerziteta u Novom Sadu

Goran Miloradović, dr. sc. Institut za savremenu istoriju, Beograd

Olivera Milosavljević, prof. dr. sc. Odelenje za sociologiju Filozofskog fakulteta Univerziteta u Beogradu

Giuseppe MotтA, dr. sc. Sapienza - Università di Roma

Božo Repe, prof. dr. sc.

Oddelek za zgodovino, Filozofska fakulteta Univerze $v$ Ljubljani

Barbara Riman, dr. sc.

Inštitut za narodnostna vprašanja, Ljubljana 
Drago Roksandić, prof. dr. sc. Odsjek za povijest Filozofskog fakulteta Sveučilišta u Zagrebu

Mateusz SoKuLSKI

Doktorand na Institutu za povijest Sveučilišta u Wrocławu

\section{Nebojša Stambolija}

Institut za savremenu istoriju, Beograd
Veljko Stanić

Balkanološki institut SANU, Beograd

Aleksandar STOJANOvić

Institut za noviju istoriju Srbije, Beograd

František ŠísteK, dr. sc.

Institut za povijest, Češka akademija znanosti, Prag 